\title{
EFFECTS OF ORGANIZATIONAL CULTURE AND QUALITY OF HUMAN RESOURCES ON THE EFFECTIVENESS OF POST-DISASTER REHABILITATION AND RECONSTRUCTION PROGRAMS IN SUB-DISTRICTS KUTA RAJA AND LUENG BATA, THE CITY OF BANDA ACEH, INDONESIA
}

\author{
Henny Dwi Purnamasari \\ Ph.D candidate, University of Satyagama \\ Dewi Sulistyani \\ Senior Lecturer, University of Satyagama \\ Budi Supriyatno \\ Senior Lecturer, University of Satyagama \\ DOI: $10.31364 / \mathrm{SCIRJ} / \mathrm{v} 7 . \mathrm{i} 8.2019 . P 0819682$ \\ http://dx.doi.org/10.31364/SCIRJ/v7.i8.2019.P0819682
}

\begin{abstract}
This study aims at determining the effects of organizational culture and the quality of human resources on the effectiveness of the Post Disaster Rehabilitation and Reconstruction Programs in Kuta Raja and Lueng Bata Sub districts, the city of Banda Aceh, Indonesia. The significance of this study is due to the fact of the ineffectiveness of post-disaster rehabilitation and reconstruction programs undertaken by the local government and community in the Kuta Raja and Lueng Bata Sub-districts, Banda Aceh City, Indonesia. Methods to collect the data were conducted by both quantitative and qualitative survey using questionnaires, in-depth interview and field observations. These data were then statistically analysed by using multiple regression analysis. In addition to that, secondary data published by the local government and the National Disaster Management Agency (BNPB) were also collected to support the analysis. The results showed that both organizational culture and the quality of human resources partially and jointly have significant effects on the effectiveness of the implementation of the Post-Disaster Rehabilitation and Reconstruction Programs in these two sub-districts. Therefore, to make the implementation of the programs works effectively, serious attention toward local culture to response the natural disaster needs to be given by the governments. The governments should also educate and train the community how to response the natural disasters before as well as after the disaster happening.
\end{abstract}

Keywords: Organizational Culture, Human resources Quality, Effectiveness of the Post-Disaster Rehabilitation and Reconstruction Programs.

\section{INTRODUCTION}

Natural disasters can occur at any time and often cause casualties, both in the form of property and human lives. For this reason, disaster management needs to be corrected sustainably by the government and the community in order to reduce the risk of disasters. One of the most devastating natural disasters that cost many lives and assets throughout Indonesia's history is the earthquake that followed by the tsunami in Aceh in 2004. Learning from this natural disaster, the Indonesian government has made many efforts to minimise the disasters. One of these efforts is by establishing the National Disaster Management Agency locally called Badan Nasional Penangulangan Bencana (BNPB). This national body was established after the tsunami disaster on April 162005 (Agustiawan, 2016). 
The above natural disaster occurred in Banda Aceh City in 2004 has caused many damages in the city of Banda Aceh. Apart from the death of many people, it also destroyed infrastructures, including settlements, social facilities such as buildings of education, health, security, social, public economy and government buildings. This disaster has also affected the social and economic conditions of the community including psychological conditions and the level of their welfare. Damage to various infrastructure facilities has also paralysed the community activities in various fields of life. As a consequence, the government of Banda Aceh City together with the central government introduced the rehabilitation and reconstruction programs under the management of the Aceh City National Disaster Management Agency (BNPBA) (Sukmaniar, 2007).

The efforts to rehabilitate and reconstruct Aceh in the aftermath of the disaster certainly require an active role from all parties involved. Various development programs were carried out to accelerate the recovery of the socio-economic conditions of the community and the provision of infrastructure. The participation of organizations and the community are also considered important. This community participation was formed through the community based development programs (Sukmaniar, 2007).

However, in carrying the post-disaster rehabilitation and reconstruction programs, the consultant parties that have been trusted to rehabilitate and reconstruct the post disaster conditions were found to be ineffective. Apart from the lack of the quality of human resources, attention toward the local culture have been considered unsatisfactory. Due to these reasons, this study aims at examining whether or not the local culture and the quality of human resources partially and jointly affect the effectiveness of the implementation of the Post-Disaster Rehabilitation and Reconstruction Programs, taking Kuta Raja and Lueng Bata SubDistricts of Banda Aceh City as study's locations. From this study, it is expected that both local and central governments will be able to implement the Post Disaster Rehabilitation and Reconstruction programs will be effective in the near future. Also, it is expected that findings derived from this study can be useful for the effective improvement of the programs in other regions of Indonesia.

\section{RESEARCH METHOD}

The methods used to collect the data were by using both quantitative and qualitative survey. The quantitative survey was taken by distributing questionnaires to the sample respondents, while the qualitative data was collected by using in-depth interviews and field observation in the two sub-districts of Kuta Raja and Lueng Bata, Banda Aceh City. In depth interviews were undertaken with the head of Infrastructural office, the head of city planning agency in the city of Banda Aceh and the local informants who live in the sub districts on Kuta Raja and Lueng Bata. In addition to the survey, secondary data published by the local government and the National Disaster Management Agency (BNPB) were also collected to support the analysis. To estimate the model, the multiple regression analysis was used. However, before the model was statistically analysed, the tests of reliability and validity of the data as well as the OLS assumptions were also examined by using SPSS version 25.

\section{RESULTS AND DISCUSSION}

\section{Characteristics of the Sub-districts}

Lueng Bata Subdistrict as one survey location is one of the areas that is still developing. This sub-district consists of nine villages, namely: (1) Gampong Lamdong, (2) Gampong Cot Mesjid, (3) Gampong Batoh, (4) Gampong Lueng Bata, ( 5) Gampong Blang Cut, (6) Gampong Lampaloh, (7) Gampong Sukadamai, (8) Gampong Panteriek, and (9) Gampong Lamseupeung.

Primary activity that usually undertaken in the post-disaster reconstruction program is the construction of mosque especially historical mosques like Jami 'lueng bata mosque that holds a high historical value for the city of Banda Aceh in the form of a long historical journey from the Acehnese struggle against Dutch colonialists. The new Jami Mosque is being renovated again in order to accommodate more pilgrims. In addition, the ongoing development in Lueng Bata District is in the form of housing development for poor people in rural areas, shops, cafes and restaurants.

Like the sub-district Luen Bata, Kuta Raja sub-district consists of 6 six villages, namely: (1) Gamong Lampaseh Kota, (2) Gampong Merduati, (3) Gampong Keudah, (4) Gampong Peulanggahan, (5) Gampong Jawa, and (6) Gampong Pande. However, one of the priorities in the historical value of reconstruction in Kuta Raja District is the Gampong Pande. This village is one of the oldest residential areas and it is as the origin of the city of Banda Aceh. In this village there are many historical relics such as the tombs of ancient kings of Aceh. As a consequence, archaeologists and historians used to visit this village for undertaking research. 
The local government of Banda Aceh City established a tsunami early warning system and evacuation buildings as the part of the post disaster rehabilitation and reconstruction programs. As shown at Table 1, there are three villages that have a Tsunami Early Warning system (TEWS) equipment. These TEWSs located in Gampong Blang Oi, Gampong Lampulo and Gampong Bandar Baru. Also, the number of evacuation buildings available in the city of Banda Aceh are three (Table 1).

Table 1. Location of TEWS and Evacuation Buildings

\begin{tabular}{|l|l|l|}
\hline No & Location & Types of development \\
\hline 1 & Gp. Blang Oi, Meuraxa & TEWS \\
\hline 2 & Gp. Lampulo, Kuta Alam & TEWS \\
\hline 3 & Gp. Bandar Baru, Kuta Alam & TEWS \\
\hline 4 & Gp. Alue Deah Teungoh,Meuraxa & Evacuation Building \\
\hline 5 & Gp. Deah Glumpang, Meuraxa & Evacuation Building \\
\hline 6 & Gp. Lambung. Meuraxa & Evacuation Building \\
\hline
\end{tabular}

Note : Gp = Gampong or village.

Source : Statistics of Banda Aceh City, 2018.

Apart from the above programs, the local government also introduced education and training programs. This program is given to the students, the staffs of local government, Non-government organisations (NGOS), the youth and other volunteers. The length of this program on average is for two days (Table 2). The objectives of this program are to : (1) increase the capacity of local staffs government in disaster management, (2) to give response to disaster and improve the skilled of personnel in disaster management, (3) increase awareness of the staffs toward disaster to name just a few.

Table 2. Types of Education and Training Program, the duration of the program and number of participants

\begin{tabular}{|c|c|c|c|c|c|c|c|c|}
\hline \multirow[b]{2}{*}{ NO } & \multirow[b]{2}{*}{ Types of Education and Training } & \multirow[b]{2}{*}{ Time held } & \multirow{2}{*}{$\begin{array}{l}\text { Duratio } \\
\mathrm{n} \text { of the } \\
\text { progra } \\
\mathrm{m}\end{array}$} & \multicolumn{5}{|c|}{ Number of participants (persons) } \\
\hline & & & & 2015 & 2016 & 2017 & 2018 & 2019 \\
\hline 1 & Students Training & October 2015 & 1day & 29 & - & - & - & - \\
\hline 2 & $\begin{array}{llll}\begin{array}{l}\text { Training } \\
\text { volunteers }\end{array} & \text { given } & \text { to } & \text { Youth } \\
\end{array}$ & December 2015 & 2 days & 40 & - & - & - & - \\
\hline 3 & Basic Training for Local Staffs & January 2016 & 2 days & - & 30 & - & - & - \\
\hline 4 & $\begin{array}{l}\text { Workshop and training toward } \\
\text { emergency response of disaster }\end{array}$ & March 2017 & 4 days & - & - & 57 & - & - \\
\hline 5 & $\begin{array}{l}\text { Training for Financial Plan of } \\
\text { Disaster program }\end{array}$ & October 2017 & 2 days & - & - & 70 & - & - \\
\hline 6 & $\begin{array}{l}\text { Training toward Forest and land } \\
\text { Fire }\end{array}$ & October 2018 & 3 days & - & - & - & 40 & - \\
\hline & $\begin{array}{l}\text { Training to develop Assessment } \\
\text { Index Regional Resilience and } \\
\text { Disaster Risks }\end{array}$ & April 2019 & 3 days & - & - & - & - & 60 \\
\hline
\end{tabular}

Source : LKJ BPB Kota Banda Aceh, 2019.

\section{The Scope and Budget Plan of the Post Disaster Rehabilitation and Reconstruction Programs}

The scope of the Post-Disaster Rehabilitation and Reconstruction Programs consist of three major activities. The first program relates to official administrative services. The activities under this program are two, namely, facility services of communication, water and electricity, and facility services toward electrical and buildings infrastructures. The second program relates to the maintenance services including maintenance services of official infrastructures, and buildings and housing. The third program is rehabilitation and reconstruction services including verification, monitoring and valuing and coordinating the damages made by the disaster.

As shown at Table 3, in terms of official administrative services program, the outcome of the facility services of communication, water and electricity in 2018 was about 12 records, while in terms of the services given to this item was about 357 units. Also, it can be seen the unit number of routine maitenance of car facilities in 2018 was 26 units, while for the maintanance of housing and government buildingsd was 75 units. The coordination of the implementation of the rehabilitation and reconstruction of the disaster was carried out at 150 people / times for 23 districts / cities, meaning 150 people were carried 
out in 23 districts / cities, while the results of the coordination of disaster damage assessment were in the form of one report. Details of this program and the achievement of this program in 2018 were given at Table 3.

Table 3. The Scope and the achievements of the Post-Disaster Rehabilitation and Reconstruction Programs

\begin{tabular}{|c|c|c|c|c|c|}
\hline NO & Program Description & Regional Goals & Input & Output & Outcome \\
\hline \multicolumn{6}{|c|}{ Official administrative Services Programs } \\
\hline 1 & $\begin{array}{l}\text { Facility services of } \\
\text { communication, water } \\
\text { and electricity }\end{array}$ & $\begin{array}{l}\text { Transparency and } \\
\text { accountability of the } \\
\text { government regulator }\end{array}$ & $\begin{array}{l}\text { Official } \\
\text { administrative } \\
\text { services }\end{array}$ & $\begin{array}{l}\text { Record of the Number } \\
\text { of electricity, telephone, } \\
\text { water and internet } \\
\text { installment }\end{array}$ & 12 Record \\
\hline 2 & $\begin{array}{l}\text { Facility services of } \\
\text { electricity and building } \\
\text { components }\end{array}$ & & & $\begin{array}{l}\text { Number of units } \\
\text { component provided for } \\
\text { office electricity }\end{array}$ & 357 Units \\
\hline \multicolumn{6}{|c|}{$\begin{array}{l}\text { Infrastructures Facility Maintenance } \\
\text { programs }\end{array}$} \\
\hline 3 & $\begin{array}{lr}\text { Routine and } & \text { timely } \\
\text { Maintenance } & \text { of } \\
\text { official } & \text { and } \\
\text { operational cars } & \end{array}$ & $\begin{array}{l}\text { Transparency and } \\
\text { accountability of the } \\
\text { government regulator }\end{array}$ & $\begin{array}{l}\text { Infrastructures } \\
\text { Facility } \\
\text { Maintenance }\end{array}$ & $\begin{array}{l}\text { Numbers of vehicle } \\
\text { units maintained }\end{array}$ & 26 units \\
\hline 4 & $\begin{array}{lr}\text { Routine and } & \text { timely } \\
\text { Maintenance } & \text { of } \\
\text { official } & \text { and } \\
\text { operational } & \text { office } \\
\text { infrastructure } & \end{array}$ & & & $\begin{array}{l}\text { Availability of } \\
\text { maintenance services of } \\
\text { office equipment }\end{array}$ & 75 units \\
\hline 5 & $\begin{array}{lr}\text { Light and } & \text { heavy } \\
\text { maintenance } & \text { of } \\
\text { housing and } & \text { official } \\
\text { buildings } & \\
\end{array}$ & & & $\begin{array}{ll}\text { Office } & \text { building } \\
\text { maintained } & \end{array}$ & 2 units \\
\hline \multicolumn{6}{|c|}{ Disaster Reconstruction and Rehabilitation Programs } \\
\hline 6 & $\begin{array}{l}\text { Inventarist, Verifying } \\
\text { and validation of } \\
\text { disaster damages }\end{array}$ & $\begin{array}{l}\text { Management of Pra, } \\
\text { Emergency Response } \\
\text { and Post Disaster }\end{array}$ & $\begin{array}{l}\text { Improvement of } \\
\text { Post Disaster } \\
\text { Rehabilitation and }\end{array}$ & $\begin{array}{l}\text { Data on the damaged } \\
\text { cause by Natural } \\
\text { Disaster }\end{array}$ & 1 document \\
\hline 7 & $\begin{array}{lr}\text { Coordination } & \text { of } \\
\text { reconstruction } & \text { and } \\
\text { Rehabilitation } & \text { of } \\
\text { damages } & \end{array}$ & & Reconstruction & $\begin{array}{lr}\text { Coordination } & \text { toward } \\
\text { recovery } & \text { and } \\
\text { Rehabilitation } & \text { at Disater } \\
\text { areas } & \end{array}$ & $\begin{array}{l}150 \\
\text { Persons }\end{array}$ \\
\hline 8 & $\begin{array}{lr}\text { Coordination } & \text { of } \\
\text { Disaster } & \text { damages } \\
\text { valuation } & \end{array}$ & & & $\begin{array}{l}\text { Coordination on the } \\
\text { assessment of lost and } \\
\text { damaged caused by the } \\
\text { disaster }\end{array}$ & 1 report \\
\hline
\end{tabular}

Source: National Disaster Management Agency (BNPBA), 2018.

In terrms of the budget plan for the fiscal year of 2019, as can be seen at Table 4 that there are 7 programs that are going to be implemented in 2019. These seven programs are Adminstrative Services Program, Human resources development program, Improvement of the disciplinary of human resources program, Early warning system and Disaster Casualty management Programs, Institutional Strengthening Program, Disaster Rehabilitation and Reconstruction Programs and Disaster Emergency Response and Logistic Programs. Of these programs, the budget for the improvement of the quality of human resources has the lowest value the lowest. Whilst the budget for the Institutional strengthening program has the higshest value followed by the budget for Disaster Emergency Response and Logistic Programs. This indicates that there is a lack attention to improve the quality of human resources to manage the natural disaster. 
Table 4. The Budget Estimate Plan of The national Disaster Management Agency in 2019 (in Rupiah)

\begin{tabular}{|l|l|l|l|}
\hline NO & Program Description & $\begin{array}{l}\text { Indicative budget } \\
\text { estimate }\end{array}$ & $\begin{array}{l}\text { Budget Prediction } \\
2019\end{array}$ \\
\hline 1 & Adminstrative Services Program & $3305196295,-$ & $4041070921,-$ \\
\hline 2 & Human resources development program & 1175000000, & $2442327250,-$ \\
\hline 3 & Improvement of the disciplinary of human resources & $8500000,-$ & $71500000,-$ \\
\hline 4 & $\begin{array}{l}\text { Early warning and Disaster Casualty management } \\
\text { Programs }\end{array}$ & $1200000000,-$ & $7312500000,-$ \\
\hline 5 & Institutional Strengthening Program & $37274013200,-$ & $50553777618,-$ \\
\hline 6 & Disaster Rehabilitation and Reconstruction Programs & $2534810996,-$ & $16315000000,-$ \\
\hline 7 & Disaster Emergency Response and Logistic Programs & $7463879149,-$ & $36900000000,-$ \\
\hline
\end{tabular}

Source: National Disaster Management Agency, 2018

Note that, concern to the involvement of the organisational culture and the improvement of the quality of human resources in the rehabilitation and the reconstruction programs in Aceh province have been introduced since 2006. However, the design to involve both organizational culture and the quality of human resources in the program began since 2005 after the 2004 tsunami disaster. These programs were issued in the Regulation of National Disaster Protection Agency (BNPB), Number 11 of 2008 concerning the Post Disaster Rehabilitation and Reconstruction programs. The aim of these programs at: (1) providing references for organizer of rehabilitation, (2) ensuring order and the success of the implementation of rehabilitation, and (3) ensuring the achievement of rehabilitation goals. Activities to rehabilitate are undertaken by: (a) improving the disaster areas, (b) improving public infrastructure and facilities, (c) providing assistance for building community housing, (d) recovering community psychology, (e) health services, (f) reconciliation and resolution conflicts, (g) Socio-economic and cultural recovery, (h) Restoration of security and order, (i) Restoration of government functions; and (j) Restoring the function of public services.

\section{Results of Multiple Regression Model}

After undertaking reliability and validity tests to the data collected, it was found that the highest validity value is the sixth statement, namely, the indicator of management's attention to the technique $(0.563)$, the tenth statement of the indicators of work activity (0.563), and the seventh statement of the management's attention to process $(0.562)$. This means that these indicators predominantly influence the Effectiveness of the Post Disaster Rehabilitation and Reconstruction Program. This finding is in line with the view of Stoner et. Al. (1995) which defines organizational culture as a cognitive framework that includes attitudes, values, behavioural norms and expectations contributed by members of the organization. This suggests that attention must be given toward the organizational culture, organizational management and organization's actions in taking risks on one hand and encouraging the organization on the other hand. Organizational encouragement can be in the form of providing motivation to strengthen the organization's culture itself.

In terms of the validity test, it was found that the eight statement of the securities effect has the lowest value of 0.218 . This means that special attention is needed to the this indicator. This finding was supported by Kreitner and Knicky (1995) in that they pointed out that organizational culture acts as a social glue that ties all organizational members together. Therefore, there should be a serious attention to organizational culture in the management process in order to obtain good results.

In terms of the test validity of the human resources quality, the study found that the sixth statement of having knowledge and skills in the field of science and technology indicator have the highest validity value of (0.567), followed by the tenth statement of adaptive attitude indicators toward foreign cultural values with the value of 0.567 . This means that these indicators predominantly influence the effectiveness of post-disaster rehabilitation and reconstruction programs (Y). While the lowest value of validity is the eight statement of having high enthusiasm and strong struggle indicators of 0.265 . This means that special attention is needed to the indicators of high morale and resilience.

After completing the validity and reliability tests of the data and the OLS assumption tests, the multiple regression model was then estimated. As shown below the estimated model is as follows.

$$
\mathrm{Y}=0.394+0.274 \mathrm{X}_{1}+0.716 \mathrm{X}_{2}
$$

Where :

$\mathrm{Y}=$ Effectiveness of the Post Disaster Rehabilitation and Reconstruction Programs

a $\quad=$ constant

b1, b2 = coefficients 


$$
\begin{array}{ll}
\mathrm{X} 1 & =\text { Organizational culture } \\
\mathrm{X} 2 & =\text { the quality of human resources }
\end{array}
$$

From the model above, it can be seen that the quality of human resources have positive and larger coefficient than the organizational culture. The coefficient of the quality human resources was 0.716 which indicates that for every one unit change (increase or decrease) of the quality of human resources, the effectiveness of the post disaster rehabilitation and reconstruction programs will change (increase or decrease) by 0.716 . Whilst changes (if there is or there is no) of one unit of the organizational culture will only result changes of the effectiveness of Post Disaster of Rehabilitation and Reconstruction programs by 0.274 . Both coefficients are positive that mean that the effects of these two variables will be linear to the changes of the effectiveness of the post disaster rehabilitation and reconstruction programs.I

The results of hypothesis testing of whether or not organisational culture and the quality of human resources are partially and jointly affect the effectiveness of rehabilitation and reconstruction programs are shown at Table 5. As can be seen at this Table, both of the independent variables of organisational culture and the quality of human resources are partially affected significantly on the effectiveness of rehabilitation and reconstruction programs. This was shown from the $t$ values and from the probability values. Both $t$ values are greater than $t$ tables. Similarly, the probability values are also less than 0.05 . The jointly effects of the two independent variables on the effectiveness of rehabilitation and reconstruction programs were also significant as shown from the $\mathrm{F}$ value and the probability value. These suggest that organisational culture and the quality of human resources play significant effects on the effectiveness of rehabilitation and reconstruction programs.

Table 5. The Result of t-tests and probability values of the Independent variables

\begin{tabular}{|l|c|c|c|c|c|}
\hline \multirow{2}{*}{ Model } & \multicolumn{2}{|c|}{$\begin{array}{c}\text { Unstandardized } \\
\text { Coefficients }\end{array}$} & $\begin{array}{c}\text { Standardized } \\
\text { Coefficients }\end{array}$ & \multirow{2}{*}{ Sig. } \\
\cline { 2 - 4 } & $\mathrm{B}$ & $\begin{array}{c}\text { Std. } \\
\text { Error }\end{array}$ & Beta & T values & 0.510 \\
\hline $\begin{array}{l}\text { (Constant) } \\
\text { Organizational } \\
\text { culture }\end{array}$ & 0.394 & 0.771 & & 3.808 & 0.000 \\
\hline $\begin{array}{l}\text { Quality of Human } \\
\text { resources }\end{array}$ & 0.716 & 0.072 & 0.268 & 10.295 & 0.000 \\
\hline
\end{tabular}

Source: calculated by using SPSS Version 25 (2019).

The result of the coefficient of determination (denoted by $\mathrm{R}^{2}$ ) a key output of regression analysis also confirmed the estimated model. As exhibited at Table 6, the $\mathrm{R}^{2}$ was 0.978 that suggests that about 98.7 per cent of the variance in the effectiveness of rehabilitation and reconstruction programs that is predictable from the organisational culture and the quality of human resources.

Table 6.

\begin{tabular}{|c|c|c|c|c|}
\hline \multicolumn{5}{|c|}{ Model Summary } \\
\hline Model & $\mathrm{R}$ & R Square & $\begin{array}{l}\text { Adjusted R } \\
\text { Square }\end{array}$ & $\begin{array}{l}\text { Std. Error of the } \\
\text { Estimate }\end{array}$ \\
\hline 1 & $0,989^{\mathrm{a}}$ & 0,978 & 0,978 & 0,544 \\
\hline
\end{tabular}

The Coefficient of Determination

Sumber : data diolah, SPSS Version 25 (2019)

In summing up: the results of the multiple regression show that both organisational culture and the quality of human resources partially and jointly affected significantly the effectiveness of the post disaster rehabilitation and reconstruction programs. Of the two independent variables estimated, the quality of human resources has the largest contribution in affecting the effectiveness of the Post Disaster Rehabilitation and Reconstruction programs.

\section{CONCLUDING NOTES}

The Post Disaster Rehabilitation and Reconstruction programs in the City of Banda Aceh, Indonesia especially in the two sub-districts of Kuta Raja and Lueng Bata have been introduced since 2004 when the tsunami disaster occur in this place. The local government of the city of Banda Aceh has implemented many rehabilitation and reconstruction programs. Apart from training and educational programs given to the local community and other relevant stakeholders, the local government has also 
introduced Tsunami Early warning systems (TEWSs) and developed evacuation buildings in many sub districts located in the city of Banda Aceh.

To make the implementation of this programs effective, this study found that the government needs to give concern toward the organisational culture on one hand and the quality of human resources. However, of these two variables, the improvement of the quality of human resources seems to be a must as this variable gives the larger contribution than the organizational culture.

In addition to that, the local government needs to strengthen the management of post-disaster organizations and improving the quality of human resources through training and education sustainably. Training and education should be given not only to the officials, but also other parties, including Non-governmental organizations (NGOs), Universities, Community Groups especially school children aged 7- 12 Years, to name a few. Thus, much remain to be done by the government of the City of Banda Aceh and the central government of Indonesia.

\section{REFERENCES}

[1] Agustiawan, Yossi.2016. Pemanfaatan Teknologi Informasi untuk Mendukung Upaya Peningkatan Kapasitas Konsultan Lokal Dalam Menangani Proyek asca Bencana Alam. Jombang; Jurnal Teknologi UNIPDU

[2] Sukmaniar.2007.Efektivitas Pemberdayaan Masyarakat Dalam Pengelolaan Program Pengembangan Kecamatan (PPK) Pasca Tsumani di Kecamatan Lhoknga Kabupaten Aceh Besar. Magister Teknik Pembangunan Wilayah dan Kota: Universitas Diponegoro.

[3] Rakasiwi, Evan Sarli.2018. Efektivitas Badan Penanggulangan Bencana Daerah (BPBD) Kota Bandar Lampung Dalam Penanggulangan Bencana Banjir di Kota Bandar Lampung. Jurnal Imu Sosial dan Politik; Universitas Lampung

[4] Sugiyono. 2010. Metode Penelitian Pendidikan. Bandung: Alfabeta.

[5] NBNPBA. Renja SKPA BNPB 2018; Aceh

[6] BNPB.2018.Renja SKPA BNPB 2018; Jakarta

[7] BPS Kota Banda Aceh.2018.Kota banda Aceh dalam angka 2018;

[8] BPS Kota Banda Aceh.2018.Kecamatan Lueng Bata dalam angka 2018; Kota Banda Aceh

[9] BPS Kota Banda Aceh.2018.Kecamatan Kuta Raja dalam angka 2018; Kota Banda Aceh

[10] BPS Kota Banda Aceh.2018.Kota banda Aceh dalam angka 2018; Kota Banda Aceh

[11] BPB Kota Banda Aceh.2019. LKJ BPB Kota Banda Aceh 2015-2019;Kota Banda Aceh 